$\overline{\bar{M}}$

\title{
世代別積立方式に基づく公的年金制度への移行方法*
}

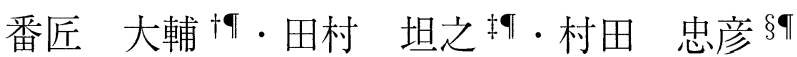

\section{Transferring Method to Generation-based Funding Scheme in Public Pension Planning*}

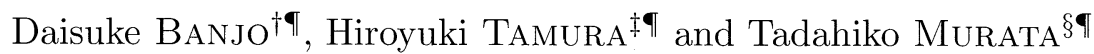

\begin{abstract}
In this paper, we propose transferring methods from the present pay-as-you-go scheme to a generation-based funding scheme. We make a mathematical model for the public pension system consisting of national pension, employee pension and mutual pension. Simulating the mathematical model the necessary government contribution is evaluated for the case with or without transferring to the generation-based funding scheme where we take into account the demographic structural change and the variation in economic situation.
\end{abstract}

\section{1.はじめに}

日本の公的年金制度は事実上の賦課方式で運営されて おり，保険料納付者から納付された保険料の大半はその 時点の年金受給者の年金として給付されている。そのた め, 少子高齢化による保険料納付者の減少と年金受給者 の増加が続くと, 保険料の上昇と年金額の下落が伴う. 保険料と年金額の度重なる変化は，保険料負担と年金給 付の比率（以下，負担給付比率）の格差をもたらし，世 代間格差の原因となっている $[1-5]$.

日本の公的年金制度には，世代間公平性だけでなく， 財政的持続可能性の点でも問題があるといえる. 賦課方 式の公的年金制度を運営するうえで重要な原則として 「収支相当の原則」すなわち各年度における保険料収入 の総額と年金支出の総額が等しくならなければならない

\footnotetext{
* 原稿受付 2008 年 3 月 5 日

$\dagger$ 関西大学 大学院工学研究科 Graduate School of Engineering, Kansai University; 3-3-35, Yamate-cho, Suita, Osaka 564-8680, JAPAN

‡関西大学 システム理工学部 Faculty of Engineering Science, Kansai University; ditto

$\S$ 関西大学 総合情報学部 Faculty of Informatics, Kansai University; 2-1-1, Ryozenji-cho, Takatsuki, Osaka 5691095, JAPAN

【関西大学 政策グリッドコンピューティング実験センター Policy Grid Computing Laboratory, Kansai University; 3-3-35, Yamate-cho, Suita, Osaka 564-8680, JAPAN Key Words: public pension planning, generation-based funding scheme, fiscal system.
}

という原則がある. 公的年金制度の恩恵を受ける年金受 給者に対してその支え手である保険料納付者が十分にい れば低額の保険料で済むが，そうでなければ多額の保険 料が必要になり，年金受給者を支えきれなくなって公的 年金財政そのものが破綻する可能性がある。

過去に筆者らは，少子高齢化に対応した公的年金制 度の財政方式として「世代別積立方式」を提案してき た[6-8]. 世代別積立方式は，その名のとおり，世代別に 保険料を積み立てる財政方式である．世代別積立方式は， 予測が困難な出生率を考慮せずに政策変数を決めること ができる点があるなど，人口構造の変化に対して頑強な 財政方式である。また，貨金上昇率や運用利率が変化す る中でも一定の負担給付比率を維持することが可能であ り，経済変数の変化に対しても頑強な財政方式といえる.

本論文では，保険料の納付開始年齢に達していない 1990 年以降生まれ世代には世代別積立方式を適用し, 他 の世代には現行の財政方式を適用する移行方法を検討す る。ただし，1990年という值は暫定的な值であり，納付 開始年齢に達していない世代であれば，任意に選ぶこと が可能である。移行方法について検討するために現行方 式の財政収支をモデル化し，世代別積立方式に移行する 場合とそうでない場合の国庫負担の推移を示す.

\section{2. 世代別積立方式への移行方法}

\section{1 現行の公的年金制度}

日本の公的年金制度は，国民年金，厚生年金および共 済年金から構成されており, 公的年金制度全体の積立金 
残高は平成 16 年度末の簿価ベースで約 198 兆円となっ ている，公的年金制度に扔ける主な歳入は，保険料納付 者からの保険料，積立金の運用利回り，国庫負担の三つ である。逆に主な歳出は，年金受給者への年金である。 また，厚生年金と共済年金から国民年金に対して基礎年 金拠出金が拠出されている。本論文では，国民年金，厚 生年金，共済年金に分けて財政収支を定式化するが，そ の目的は現行方式全体の積立金の推移をシミュレートす ることであり，基礎年金拠出金は全体の積立金の推移に は影響を与えないため，基礎年金拠出金の定式化を省略 する。

日本の公的年金制度に扔いて被保険者は三つに区分さ れている。第 1 号被保険者は自営業者や学生からなり, 国民年金にのみ加入している者である．第 2 号被保険者 はサラリーマンや公務員などからなり，国民年金と厚生 年金もしくは共済年金に加入している者である。第 3 号 被保険者は第 2 号被保険者に扶養されている配偶者から なっており，国民年金にのみ加入している者である.

\section{2 世代別積立方式}

世代別積立方式の概要を Fig. 1 に示す. 世代別積立方 式は，世代別の積立金と変動準備金からなる。世代別の 各積立金は金融市場で運用され，その運用利回りは貨幣 価值の変化に基づいて世代別の各積立金と変動準備金に 配分して積み立てられる。また，仮に変動準備金が底を つくような場合には，国庫負担によって積み立てが行わ れる.

賦課方式は世代間の相互扶助を目的として設計されて いるため，その方式のもとでは各世代の保険料や年金額 は他の世代の影響，とりわけ人口の多少によって保険料 や年金額が大きく影響を受ける，それに対して世代別積 立方式のもとでは世代別に保険料の積み立てと年金の給 付が行われる。つまり，資金の管理・運用が世代間で独 立しているため，他の世代，たとえば自分より若い世代 の人口が少なくても，その影響を受けることがなく，人 口構造の変化に強い財政方式といえる.

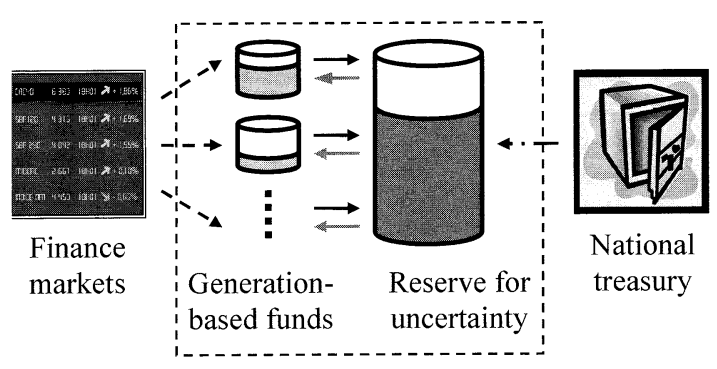

The public pension system

$\rightarrow$ : Returns from finance markets

+- : Shortage of reserve for uncertainty

$\longrightarrow$ : Surplus returns

$\leftarrow$ : Shortage of generation-based funds

Fig. 1 The outline of generation-based funding scheme

\section{3 移行方法}

世代別積立方式への移行方法の概要を Fig. 2 に示す. 本論文では, 1989 年以前生まれの世代には現行方式を適 用し, 1990 年以降生まれの世代に対して世代別積立方式 を適用する移行方法を検討する。

世代間公平性を維持するうえでは，1989年以前生ま れの世代に対しても世代別積立方式を適用し，これらの 世代に対しても出生年に因らず一定の負担給付比率を維 持することが望ましい. しかしながら，これらの世代の 中には，親の世代に対して保険料による公的扶助だけで なく, 家庭内での私的扶助をすでに行っている世代もあ り，そのような私的扶助も考慮して出生年別の負担給付 比率を推計することは困難である。 また，私的扶助を考 慮せずに保険料負担だけで負担給付比率を計算すると， 保険料が低く抑えられていた世代は十分な年金が得られ なくなるため，これらの世代には現行方式を適用するこ ととする。

移行期間中，現行方式のもとでは新たな加入者がなく て保険料納付者が減少し, 年金受給者に対する年金給付 の原資が不足する可能性がある。 それに対して新方式の もとでは, 当初, 年金受給者がゼロで歳出がなく, さら に保険料納付者の増加も続くため, 積立金残高に余裕が 生じる。そこで現行方式下において年金原資が不足する 場合には，新方式下の変動準備金から不足分を補填する こととする。世代別積立金は新方式適用世代の年金原資 に用いられるため, 現行方式下における年金原資の不足 分の補填には用いないこととする.

文献 $[6,8]$ において変動準備金は金融市場で運用され ないが, 本論文では財政的な余力を確保するために変動 準備金も金融市場で運用することとする.

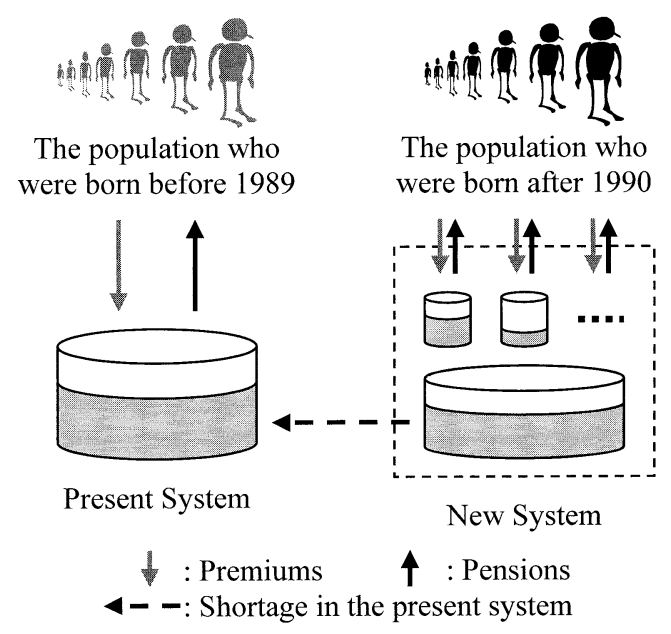

Fig. 2 Transfer to generation-based funding scheme

\section{3. 財政方式の数理モデル}

本節では，移行期間中の財政の推移をシミュレートす るため，現行方式下における財政収支と財政収支に大き な影響を与える人口構造と経済状態の変化を定式化する. 


\section{1 人口と賃金の推移}

$t$ 年において $a$ 歳である世代は $t+1$ 年に $a+1$ 歳にな り，その人口 $P(t, a)$ は $P(t+1, a+1)$ に変化する. その 変化の要因は死亡と入出国であるが, 本論文では簡単化 のために死亡のみを考慮することとし，その変化を (1) 式に示す.

$$
P(t+1, a+1)=L(t, a) P(t, a)
$$

ただし， $L(t, a)$ は生存率である

$t$ 年における勤労者全体の平均賃金 $W(t)$ は賃金上昇 率 $\omega(t)$ に基づいて毎年変化することとし，その変化を (2) 式に示す.

$$
W(t+1)=(1+\omega(t)) W(t)
$$

\section{2 国民年金の財政収支}

国民年金の財政収支のうち，まず歳入を定式化する。 国民年金の歳入 $\Delta F_{+}^{N}(t)$ は，保険料収入 $\Delta F_{+1}^{N}(t)$, 運用 収入 $\Delta F_{+2}^{N}(t)$, 国庫負担収入 $\Delta F_{+3}^{N}(t)$ 加成っている。 したがって，国民年金の歳入は $(3)$ 式のように表される。

$$
\Delta F_{+}^{N}(t)=\Delta F_{+1}^{N}(t)+\Delta F_{+2}^{N}(t)+\Delta F_{+3}^{N}(t)
$$

国民年金の保険料は被保険者の所得に因らず一定であり， その納付者は第 1 号被保険者である。したがって，保険 料収入 $\Delta F_{+1}^{N}(t)$ は

$$
\Delta F_{+1}^{N}(t)=\alpha^{N}(t) \sum_{i=\lambda_{N}}^{\phi_{N}(t)} r^{N 1}(t, i) P(t, i)
$$

のように表すことができる。ただし， $\alpha^{N}(t)$ は 1 人当た りの保険料， $\lambda_{N}$ は保険料の納付開始年齢， $\phi_{N}(t)$ は保 険料納付者の最高年齢である。 $r^{N 1}(t, a)$ は第 1 号被保険 者の人口比率であり, $r^{N 1}(t, a) P(t, a)$ が当該世代におけ る第 1 号被保険者の人数となる. 運用収入 $\Delta F_{+2}^{N}(t)$ は

$$
\Delta F_{+2}^{N}(t)=\theta(t) F^{N}(t)
$$

のように表される。ただし， $\theta(t)$ は運用利率であり， $F^{N}(t)$ は国民年金の積立残高である。国庫負担は基礎年 金支出の一定割合となっている。したがって，国庫負担 収入 $\Delta F_{+3}^{N}(t)$ は

$$
\Delta F_{+3}^{N}(t)=\gamma^{N}(t) \Delta F_{-1}^{N}(t)
$$

のように表される。ただし， $\gamma^{N}(t)$ は国庫負担率であり， $\Delta F_{-1}^{N}(t)$ は基礎年金支出である.

年金受給者が受給できる年金は主に二つある。一つは 基礎年金であり，もう一つは報酬比例年金である。ただ し，国民年金から給付される年金は基礎年金のみである。 したがって国民年金の歳出 $\Delta F_{-}^{N}(t)$ は第 1 号被保険者へ の基礎年金支出 $\Delta F_{-1}^{N}(t)$ のみであり, $\Delta F_{-}^{N}(t)$ は $(7)$ 式 のように表すことができる。

$$
\Delta F_{-}^{N}(t)=\Delta F_{-1}^{N}(t)
$$

基礎年金支出 $\Delta F_{-1}^{N}(t)$ は

$$
\Delta F_{-1}^{N}(t)=\sum_{i=\psi_{N}(t)}^{\xi} u^{N}(t, i) r^{N 1}(t, i) P(t, i)
$$

のように表される.ただし， $\xi$ は人間の最長寿命, $u^{N}(t, a)$ は当該世代における 1 人当たりの基礎年金額である. $\psi^{N}(t)$ は基礎年金受給者の最低年齢である. 新規の基礎 年金受給者の基礎年金額 $Z^{N}(t)$ は，原則として，賃金上 昇率 $\omega(t)$ に基づいて更新される。ただ, 現在では財政 収支の悪化を抑えるため, 人口構造の変化を考慮したマ クロ経済スライドの調整率 $\eta(t)$ にも基づいて更新されて いる.したがって， $Z^{N}(t)$ の変化は $(9)$ 式および $(10)$ 式 のように表すことができる。

$$
\begin{aligned}
& Z^{N}(t)=\rho(t-1) Z^{N}(t-1) \\
& \rho(t)= \begin{cases}1+\omega(t)-\eta(t) & \left(t<T_{m}\right) \\
1+\omega(t) & \left(t \geq T_{m}\right)\end{cases}
\end{aligned}
$$

ただし， $T_{m}$ はマクロ経済スライドの終了年である．既存 の基礎年金受給者の基礎年金額は，原則として，物価上 昇率 $\kappa(t)$ に基づいて更新される。したがって， $u^{N}(t, a)$ は(11) 式，(12) 式および(13)式のように表される.

$$
\begin{aligned}
& u^{N}\left(t, \psi_{N}(t)\right)=\left\{\begin{array}{r}
Z^{N}(t) \\
\left(\psi_{N}(t)=\nu_{N}\left(t, \psi_{N}(t)\right)\right) \\
\tau(t-1) u^{N}\left(t-1, \psi_{N}(t)-1\right) \\
\left(\psi_{N}(t) \neq \nu_{N}\left(t, \psi_{N}(t)\right)\right)
\end{array}\right. \\
& u^{N}(t, a)=\tau(t-1) u^{N}(t-1, a-1) \\
& \tau(t)=\left\{\begin{array}{rr}
1+\kappa(t)-\eta(t) & \left(a>\psi_{N}(t)\right) \\
1+\kappa(t) & \left(t \geq T_{m}\right)
\end{array}\right.
\end{aligned}
$$

ただし， $\nu_{N}(t, a)$ は基礎年金の給付開始年齢である. (11) 式の $\psi_{N}(t)=\nu_{N}\left(t, \psi_{N}(t)\right)$ は基礎年金受給者の最 低年齢と基礎年金の給付開始年齢が等しい場合であり， $\psi_{N}(t) \neq \nu_{N}\left(t, \psi_{N}(t)\right)$ はそうでない場合である。給付 開始年齢が常に一定であれば，これらは常に等しい。 しかしながら，給付開始年齢が 60 歳から 65 歳に変 化するような場合，必ずしも基礎年金受給者の最低年 齢と基礎年金の給付開始年齢が等しいとは限らない. $\psi_{N}(t)=\nu_{N}\left(t, \psi_{N}(t)\right)$ が成り立つ場合，最低年齢の基礎 年金受給者は新規受給者として年金額が定められる。そ れに対して $\psi_{N}(t) \neq \nu_{N}\left(t, \psi_{N}(t)\right)$ の場合，最低年齢の基 礎年金受給者は前年の自らの基礎年金額とマクロ経済ス ライド率および物価上昇率に基づいて年金額が定めら れる。 


\section{3 厚生年金と共済年金の財政収支}

厚生年金の歳入 $\Delta F_{+}^{E}(t)$ は, 保険料収入 $\Delta F_{+1}^{E}(t)$, 運 用収入 $\Delta F_{+2}^{E}$, 国庫負担収入 $\Delta F_{+3}^{E}$ からなっており, (14) 式のように表される.

$$
\Delta F_{+}^{E}(t)=\Delta F_{+1}^{E}(t)+\Delta F_{+2}^{E}(t)+\Delta F_{+3}^{E}(t)
$$

厚生年金の保険料は，国民年金の保険料のように定額で はなく，賃金所得に一定の比率を乗じた金額である。こ の一定の比率は保険料率とよばれている。したがって, 厚生年金の保険料収入 $\Delta F_{+1}^{E}$ は

$$
\Delta F_{+1}^{E}=\alpha^{E}(t) W(t) \sum_{i=\lambda_{E}}^{\phi_{E}(t)} C(t, i) r^{E 2}(t, i) P(t, i)
$$

となる。ただし， $\alpha^{E}(t)$ は保険料率， $\lambda_{E}$ は保険料の納 付開始年齢, $\phi_{E}(t)$ は保険料納付者の最高年齢である. $r^{E 2}(t, a)$ は厚生年金に加入している第 2 号被保険者の 人口比率であり, $r^{E 2}(t, a) P(t, a)$ が当該世代において 厚生年金に加入している第 2 号被保険者の人数となる. $C(t, a)$ は全勤労者の平均賃金に対する当該世代に属する 勤労者の平均賃金の比率（以下，賃金構造比率）であり, $W(t) C(t, a)$ が当該世代に扔ける勤労者の平均貨金とな る。運用収入 $\Delta F_{+2}^{E}(t)$ は $(16)$ 式のと扔りである.

$$
\Delta F_{+2}^{E}(t)=\theta(t) F^{E}(t)
$$

ただし， $F^{E}(t)$ は厚生年金の積立残高である。国庫負担 は基礎年金支出の一定割合となっている。したがって, 国庫負担収入 $\Delta F_{+3}^{E}(t)$ は

$$
\Delta F_{+3}^{E}(t)=\gamma^{E}(t) \Delta F_{-1}^{E}(t)
$$

のように表される。ただし， $\gamma^{E}(t)$ は国庫負担率であり， $\Delta F_{-1}^{E}(t)$ は基礎年金支出である.

厚生年金の歳出 $\Delta F_{-}^{E}(t)$ は，基礎年金支出 $\Delta F_{-1}^{E}$ と報 酬比例年金支出 $\Delta F_{-2}^{E}$ からなっており，(18) 式となる.

$$
\Delta F_{-}^{E}(t)=\Delta F_{-1}^{E}(t)+\Delta F_{-2}^{E}(t)
$$

基礎年金支出は，厚生年金に加入している第 2 号被保険 者とその被扶養配偶者からなる第 3 号被保険者に対し て給付される基礎年金のために用いられる．1 人当たり の基礎年金額は国民年金の財政収支の定式化で示した $u^{N}(t, a)$ と同じである。したがって，厚生年金の基礎年 金支出 $\Delta F_{-1}^{E}(t)$ は $(19)$ 式拈よび $(20)$ 式となる.

$$
\begin{aligned}
& \Delta F_{-1}^{E}(t)=\sum_{i=\psi_{N}(t)}^{\xi} u^{N}(t, i) r^{E}(t, i) P(t, i) \\
& r^{E}(t, a)=r^{E 2}(t, a)+r^{E 3}(t, a)
\end{aligned}
$$

ただし, $r^{E 2}(t, a)$ は厚生年金に加入している第 2 号被保 険者の人口比率, $r^{E 3}(t, a)$ は厚生年金に加入している第
2 号被保険者の被扶養配偶者の人口比率, $r^{E}(t, a)$ はそれ らを合わせた人口比率である。報酬比例年金は第 2 号被 保険者にの及給付される。したがって，厚生年金の報酬 比例年金支出 $\Delta F_{-2}^{E}(t)$ は

$$
\Delta F_{-2}^{E}(t)=\sum_{i=\psi_{E}(t)}^{\xi} u^{E}(t, i) r^{E 2}(t, i) P(t, i)
$$

となる。ただし， $\psi_{E}(t)$ は報酬比例年金受給者の最低年 齢, $u^{E}(t, a)$ は当該世代に扮ける 1 人当たりの報酬比例 年金額である．新規の報酬比例年金受給者の報酬比例年 金額 $Z^{E}(t)$ は，全勤労者の平均貸金に給付水準とよばれ る一定の比率 $\beta^{E}(t)$ を乗じた值から，夫婦 2 人分の基礎 年金額 $2 Z^{N}(t)$ を引いた值であり，(22) 式となる.

$$
Z^{E}(t)=\beta^{E}(t) W(t)-2 Z^{N}(t)
$$

既存の報酬比例年金受給者の報酬比例年金額は，原則と して，物価上昇率 $\kappa(t)$ に基づいて更新される。ただし， 基礎年金と同様，マクロ経済スライドによっても更新さ れている。したがって, $u^{E}(t, a)$ は (23) 式と (24) 式のよ うに表される。

$$
\begin{gathered}
u^{E}\left(t, \psi_{E}(t)\right)=\left\{\begin{array}{r}
Z^{E}(t) \\
\left(\psi_{E}(t)=\nu_{E}\left(t, \psi_{E}(t)\right)\right) \\
\tau(t-1) u^{E}\left(t-1, \psi_{E}(t)-1\right) \\
\left(\psi_{E}(t) \neq \nu_{E}\left(t, \psi_{E}(t)\right)\right)
\end{array}\right. \\
u^{E}(t, a)=\tau(t-1) u^{E}(t-1, a-1) \\
\left(a>\psi_{E}(t)\right)
\end{gathered}
$$

ただし, $\nu_{E}(t, a)$ は報酬比例年金の給付開始年齢である.

な扔，共済年金は厚生年金とほぼ同じ仕組みなので, 定式化を省略する。

\section{4 世代別積立方式}

$t$ 年において $a$ 歳である世代の世代別積立金 $S(t, a)$ に 対する運用収入 $\Delta S_{+1}(t, a)$ を $(25)$ 式に示す.

$$
\Delta S_{+1}(t, a)=\kappa(t) \theta(t) S(t, a)
$$

$\kappa(t)$ は, 得られた運用利回りの何パーセントを世代別積 立金に積み立てるかということを表す運用収入積立比率 である。

ここで，貨幣価値の変化により生じる世代別積立金の 実質価值の变化分を運用収入によって補填することを考 える. $t$ 年を基準時点とした $S(t, a)+\Delta S_{+1}(t, a)$ の実質 価値 $R e\left(S(t, a)+\Delta S_{+1}(t, a), t\right)$ を (26) 式に示す.

$$
\operatorname{Re}\left(S(t, a)+\Delta S_{+1}(t, a), t\right)=\frac{1+\kappa(t) \theta(t)}{1+\omega(t)} S(t, a)
$$

運用収入によって世代別積立金の実質価値の変化分を 補填するためには, $\operatorname{Re}\left(S(t, a)+\Delta S_{+1}(t, a), t\right)$ と $S(t, a)$ が等しくなるように $\kappa(t)$ を決定すればよく, $\kappa(t)$ は 


$$
\kappa_{t}=\frac{\omega(t)}{\theta(t)}
$$

となる。したがって，運用収入 $\Delta S_{+1}(t, a)$ は, $(28)$ 式の とおりになる。

$$
\Delta S_{+1}(t, a)=\omega(t) S(t, a)
$$

世代別積立金は，運用収入だけでなく，保険料収入と年 金給付支出によっても変化する. 保険料収入 $\Delta S_{+2}(t, a)$ は, 保険料率 $\alpha^{G}(t, a)$ と就業者数 $H(t, a) P(t, a)$, さらに 平均賃金 $C(t, a) W(t)$ に比例し,

$$
\Delta S_{+2}(t, a)=\alpha^{G}(t, a) H(t, a) P(t, a) C(t, a) W(t)
$$

となる。ただし， $H(t, a)$ は就業率である。また $C(t, a)$ は, 全世代の平均賃金に対する当該世代の平均賃金の比 率（以下，賃金構造比率）である。

年金給付支出 $\Delta S_{-}(t, a)$ は, 給付水準 $\beta^{G}(t, a)$, 平均 納付率 $\zeta(t, a)$, 人口数 $P(t, a)$, さらに全世代の平均貨金 $W(t)$ に比例し，(30)式のとおりになる.

$$
\Delta S_{-}(t, a)=\beta^{G}(t, a) \zeta(t, a) P(t, a) W(t)
$$

保険料収入，年金給付支出，運用収入を合わせた世代 別積立金の収支 $\Delta S(t, a)$ は

$$
\Delta S(t, a)=\left\{\begin{array}{lr}
0 & \left(0 \leq a<\lambda_{G}(t, a)\right) \\
\Delta S_{+1}(t, a)+\Delta S_{+2}(t, a) \\
\left(\lambda_{G}(t, a) \leq a<\nu_{G}(t, a)\right) \\
\Delta S_{+1}(t, a)-\Delta S_{-}(t, a) \\
\left(\nu_{G}(t, a) \leq a \leq \xi\right)
\end{array}\right.
$$

となる. $\lambda_{G}(t, a)$ は保険料の納付開始年齢, $\nu_{G}(t, a)$ は年 金の給付開始年齢， $\xi$ は最長寿命である。納付開始年齢 未満の時点では, 運用収入や保険料収入, 年金給付支出 がないため，世代別積立金は変化しない，納付期間中に は運用収入と保険料収入が生じ, 給付期間中には運用収 入と年金給付支出が生じる.

ここで， $T$ 年において $A$ 歳である世代の世代别積立金 が $S(T, A)$ である場合に保険料率 $\alpha^{G}(T, A)$ と給付水準 $\beta^{G}(T, A)$ を決定することを考える. 当該世代の人口数が ゼロになる時点は $T-A+\xi+1$ 年であり，この時点にお ける当該世代の世代別積立金 $S(T-A+\xi+1, \xi+1)$ は

$$
\begin{aligned}
S(T-A+\xi+1, \xi+1) & =S(T, A) \\
& +\sum_{i=0}^{\xi-A} \Delta S(T+i, A+i)
\end{aligned}
$$

となる. $S(T-A+\xi+1, \xi+1)$ がゼロになるよう保険 料率と給付水準を決定すれば, 当該世代の世代別積立 金に対する保険料収入の実質価值と年金給付支出の実 質価值が均衡するが, 将来の賃金上昇率や就業率が $T$ 年において既知でないため, $S(T-A+\xi+1, \xi+1)$ の 予測值 $\hat{S}(T-A+\xi+1, \xi+1)$ に基づいて保険料率と給
付水準を毎年更新することとする．また，将来の保険 料率と給付水準は一定であると仮定して定式化を行う。 さらに, 保険料率と給付水準には上下限があるため, $\hat{S}(T-A+\xi+1, \xi+1)$ がゼロに最も近づくよう保険料率 と給付水準を決定する. 保険料率と給付水準の決定問題 を(33) 式に示す.

$$
\min _{\alpha^{G}(T, A) \beta^{G}(T, A)}(\hat{S}(T-A+\xi+1, \xi+1))^{2}
$$

subject to

$$
\begin{aligned}
& \underline{\alpha}^{G} \leq \alpha^{G}(T, A) \leq \bar{\alpha}^{G} \\
& \underline{\beta}^{G} \leq \beta^{G}(T, A) \leq \bar{\beta}^{G}
\end{aligned}
$$

$\underline{\alpha}^{G}$ は保険料率の下限であり, $\bar{\alpha}^{G}$ は保険料率の上限であ る. $\underline{\beta}^{G}$ は給付水準の下限であり, $\bar{\beta}^{G}$ は給付水準の上限 である。

$\hat{S}(T-A+\xi+1, \xi+1)$ を導出するためには, 生存率 の予測值 $\hat{L}(T+i, A+i)(i=0, \cdots, \xi-A)$ と賃金上昇率 の予測值 $\hat{\omega}(T+i)(i=0, \cdots, \xi-A)$ が必要である。また， $\lambda_{G}(T, A) \leq A<\nu_{G}(T, A)-1$ の場合, 就業率の予測值 $\hat{H}(T+i, A+i)\left(i=1, \cdots, \nu_{G}(T, A)-A-1\right)$, 賃金構造比 率の予測值 $\hat{C}(T+i, A+i)\left(i=1, \cdots, \nu_{G}(T, A)-A-1\right)$ と 平均納付率の予測值 $\hat{\zeta}(T, A)$ が必要である. 生存率の予 測は修正リー・カーター法 $[9,10]$ に基づくこととする. 賃 金上昇率の予測手法は確立されていないため, 過去 10 年 の実績值の平均值を将来の予測値として用いる.

$$
\hat{\omega}(T+i)=\frac{1}{10} \sum_{j=1}^{10} \omega(T-j) \quad(i=0, \cdots, \xi-A)
$$

就業率と賃金構造比率の変化は比較的緩やかであるため, $T$ 年の值をそのまま予測值として用いることとする.

$$
\begin{array}{r}
\hat{H}(T+i, A+i)=H(T, A+i) \\
\quad\left(i=1, \cdots, \nu_{G}(T, A)-A-1\right) \\
\hat{C}(T+i, A+i)=C(T, A+i) \\
\quad\left(i=1, \cdots, \nu_{G}(T, A)-A-1\right)
\end{array}
$$

保険料の納付率は, 経済的要因の他にも影響を受けるが, 本論文では簡単化のために就業者の全員が保険料を納付 することとする．就業者の全員が保険料を納付する場合, 保険料の納付率は就業率によって定まる。そこで $T$ 年以 前の就業率の実績值と $T+1$ 年以降の就業率の予測値か ら, 当該世代の平均納付率の予測值を求めることとする.

$$
\begin{aligned}
\hat{\zeta}(T, A) & =\frac{1}{\nu_{G}(T, A)-\lambda_{G}(T, A)} \\
& \times\left\{\sum_{j=0}^{A-\lambda_{G}(T, A)} H(T-j, A-j)\right. \\
& \left.+\sum_{j=1}^{\nu_{G}(T, A)-A-1} \hat{H}(T+j, A+j)\right\}
\end{aligned}
$$


現行の公的年金制度では，基礎年金支出の一定割合の 額の国庫負担が毎年投入されている．財政的持続可能性 を考えれば国庫負担は必要であるが，適切に行われなけ れば国庫負担が多かった世代とそうでない世代の間で負 担給付比率が異なり，世代間公平性が損なわれる。

世代別積立方式の場合，納付期間と給付期間が適切に 設定されて政策変数に十分な余裕があれば，保険料収入 の実質価値と年金給付支出の実質価值が等しく負担給付 比率が 1 になる。世代間公平性の観点からすると負担給 付比率が一定である必要があるが，必ずしも 1 である必 要はない。 そこで, 保険料の一定割合を企業（雇用主） と国庫から負担することとする。ただ，保険料の負担 比率が変化すると負担給付比率も変化するため, 全期間 および全世代を通して一定にする必要がある。

\section{4. シミュレーション方法}

世代別積立方式への移行が可能かどうかを財政的な観 点から明らかにするために財政の推移をシミュレートす る。本節では, そのシミュレーションのアルゴリズムと, シミュレーションに必要なデータを示す。

\section{1 アルゴリズム}

シミュレーション・アルゴリズムを下記に示す。

Step 1. 初期化

年齢別生存率, 賃金上昇率, 運用利率の時系列デー 夕を作成する。

Step 2. 歳入と歳出の算出

当該世代が現行方式の適用世代であれば 3.2 節およ び 3.3 節に基づき，さもなければ 3.4 節に基づき， 世代別に公的年金の歳入と歳出を算出する.

Step 3. 人口の更新

年齢別生存率に基づいて当該世代の人口を更新する.

Step 4. 年齢の更新

年齢を更新する．年齢が最長寿命を超えればStep 5 に進み，さもなければStep 2 に戻る.

Step 5. 積立金残高の更新

Step 2 で求めた世代別の歳入と歳出を足し合わせ, 現行方式下の積立金残高と世代別積立方式下の積立 金残高をそれぞれ更新する。

Step 6. 平均貨金の更新

傊金上昇率に基づいて平均賃金を更新する。

Step 7. 時間の更新

時間を進める。シミュレーション終了時点を越えれ ば終了し，さもなければStep 2 に戻る。

\section{2 データ}

シミュレーションに必要なデータを人口, 経済, 政策 およびその他に分けて示す.

\subsection{1 人ロデータ}

シミュレーション開始時点は 2005 年であるが, 世代 別積立方式の運用上, それ以前の人口も知る必要がある.
本論文では，総務省が毎年実施している人口推計の結果 を実績值として用いる，ただし，90歳以上では年齢別の データがないため，指数関数による補完を行う。例とし て 2005 年の值を Fig. 3 に示す.

Fig. 4 に 2006 年から 2100 年までの出生数を示す. 出 生数の予測值には, 国立社会保障 ·人口問題研究所が実 施している将来推計の結果（2002 年推計）を用いる.

生存率 $L(t, a)$ は常に変化しているが, その予測は比較 的容易であるため，修正リー・カーター法 $[9,10]$ に基づ く予測值を用いる.

被保険者の人口比率は変化が緩やかであるため，全期 間・全年齢を通して一定とし，社会保険庁から公開され ている 1994 から 2004 年の被保険者数の值に基づいて被 保険者の人口比率をそれぞれ推計する．被保険者の人口 比率の推計結果を Table 1 に示す.

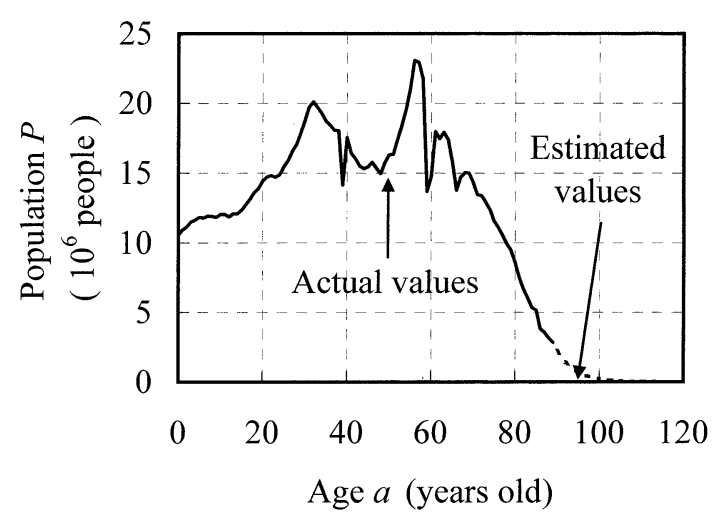

Fig. 3 Initial population

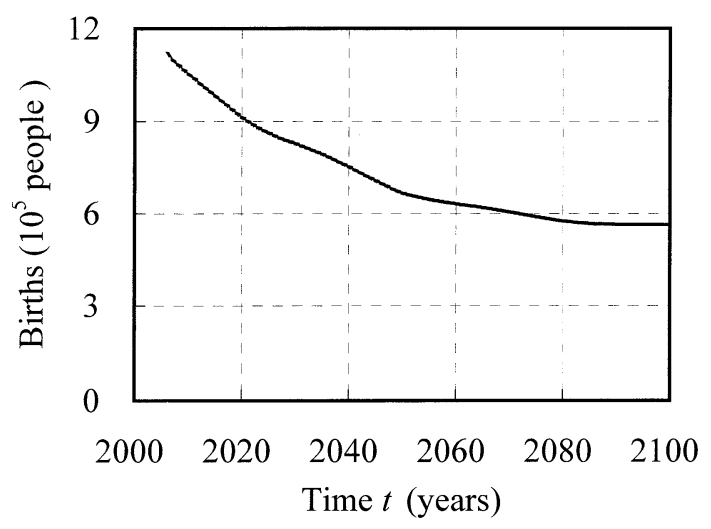

Fig. 4 Predicted values of future birthes

\subsection{2 経済データ}

Fig. 5 に就業率 $H(t, a)$ と賃金構造比率 $C(t, a)$ を示す. 総務省が実施している国勢調査の結果 $(2005$ 年調査) か ら就業率を推定する。ただし，85歳以上の就業者と人口 の調査結果がないため, それぞれを指数関数で補完し, 85 歳以上の就業率を推定する. 国勢調査の結果と厚生労 働省が実施している貨金構造基本統計調査の結果 (2005 年調查）から賃金構造比率を推定する.ただし，賃金構 造基本統計調査の結果は 5 歳ごとにしかないため, 15 歳 
Table 1 Percentages of the insured

\begin{tabular}{ll}
\hline Population ratio & $\begin{array}{l}\text { Estimated } \\
\text { values }\end{array}$ \\
\hline $\begin{array}{l}\text { The first group of the insured } r^{N 1} \\
\text { The second group of the insured }\end{array}$ & $29.7 \%$ \\
in employee pension $r^{E 2}$ & $46.0 \%$ \\
$\begin{array}{l}\text { The third group of the insured (Their } \\
\text { spouses are in employee pension) } r^{E 3}\end{array}$ & $14.1 \%$ \\
$\begin{array}{l}\text { The second group of the insured } \\
\text { in mutual pension } r^{M 2}\end{array}$ & $7.2 \%$ \\
$\begin{array}{l}\text { The third group of the insured (Their } \\
\text { spouses are in mutual pension) } r^{M 3}\end{array}$ & $2.2 \%$ \\
\hline
\end{tabular}

から 64 歳までを 2 次関数で補完し，65 歳以上を指数関 数で補完する，さらに，全世代の平均賃金の実績值と一 致するよう標準化を行う。就業率と賃金構造比率の変化 は緩やかであるため，全期間を通して一定とする。

賃金上昇率，物価上昇率拉よび運用利率を Table 2 に 示す。これらの值には, 2004 年度の財政再計算で用いら れている值をそれぞれ全期間一定として用いる。

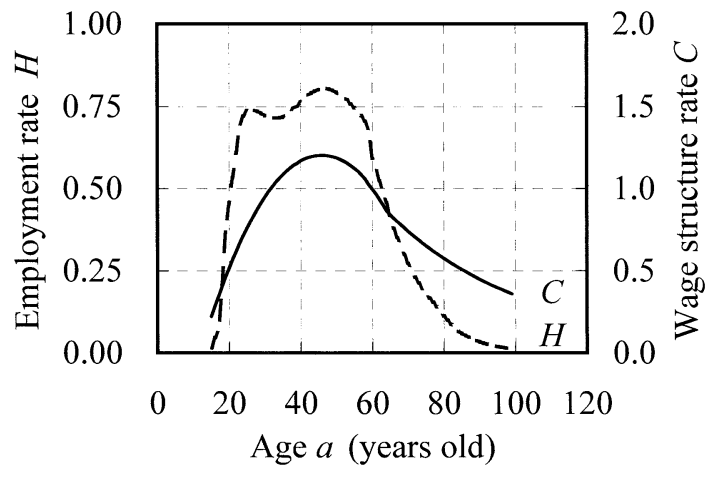

Fig. 5 Employment rate and wage structure rate

Table 2 Economical premise

\begin{tabular}{ll}
\hline Economical variable & Assumed value \\
\hline Wage growth rate $\omega$ & $2.1 \%$ \\
Price increase rate $\kappa$ & $1.0 \%$ \\
Rate of return $\theta$ & $3.2 \%$ \\
\hline
\end{tabular}

\subsection{3 政策データ}

Table 3 に初期時点の期首における国民年金，厚生年 金抢よび共済年金の積立金残高を示す。

Table 4 から Table 6 に国民年金, 厚生年金掞よび共 済年金の政策変数を示す. 保険料の納付開始年齢と保険 料抢よび保険料率の值は 2004 年度の公的年金制度改正 で定められた值である。国庫負担率は $1 / 2$ まで引き上げ られることが決まっているが，本論文ではさらに 1.0 ま で引き上げる場合のシミュレーションも行う.
Table 3 Initial pension reserve

\begin{tabular}{lr}
\hline Reserve balance & Actual value \\
\hline National pension $F^{N}$ & $10.4 \times 10^{12}$ yen \\
Employee pension $F^{E}$ & $137.7 \times 10^{12}$ yen \\
Mutual pension $F^{M}$ & $50.0 \times 10^{12}$ yen \\
\hline
\end{tabular}

Table 4 Policy variables for national pension

\begin{tabular}{ll}
\hline Policy variable & Set value \\
\hline Age for the start of & \\
contribution $\lambda_{N}$ & 20 years old \\
Payment period $\mu_{N}$ & 40 years \\
Age for the start of & \\
benefits $\nu_{N}$ & $60-65$ years old \\
Insurance $\alpha^{N}$ & $13580-16900$ yen $/$ month \\
Government share & \\
contribution $\gamma^{N}$ & $(1 / 3+1 / 1000)-1.0$ \\
\hline
\end{tabular}

Table 5 Policy variables for employee pension

\begin{tabular}{ll}
\hline Policy variable & Set value \\
\hline Age for the start of & \\
contribution $\lambda_{E}$ & 20 years old \\
Payment period $\mu_{E}$ & 40 years \\
Age for the start of & \\
benefits $\nu_{E}$ & $60-65$ years old \\
Insurance rate $\alpha^{E}$ & $13.934-18.3 \%$ \\
Benefit level $\beta^{E}$ & $59.3-50.2 \%$ \\
Government share & \\
contribution $\gamma^{E}$ & $(1 / 3+1 / 1000)-1.0$ \\
\hline
\end{tabular}

Table 6 Policy variables for mutual pension

\begin{tabular}{ll}
\hline Policy variable & Set value \\
\hline $\begin{array}{l}\text { Age for the start of } \\
\text { contribution } \lambda_{M}\end{array}$ & 20 years old \\
Payment period $\mu_{M}$ & 40 years \\
Age for the start of & \\
benefits $\nu_{M}$ & $60-65$ years old \\
Insurance rate $\alpha^{M}$ & $13.384-18.3 \%$ \\
Benefit level $\beta^{M}$ & $59.3-50.2 \%$ \\
Government share & \\
contribution $\gamma^{M}$ & $(1 / 3+1 / 1000)-1.0$ \\
\hline
\end{tabular}

Table 7 と Table 8 に世代別積立方式の政策変数を示 す. 世代別積立方式では経済状況の変化に対して自動的 に保険料率と給付水準が調整されるようになっており, 
上下限のみをあらかじめ定めることになっている．保険 料の納付開始年齢は現行方式と同じであるが, 納付期間 と年金の給付開始年齢は平均寿命が延びるとそれに合わ せて延長および引き上げられる．現行方式の厚生年金の 場合，保険料は被保険者個人とその雇用主が保険料を納 付しているが，文献 $[8]$ の世代別積立方式では被保険者個 人，雇用主に加えて国庫からも共に保険料を積み立てる 財政方式が提案されている。また，保険料率（個人分十 企業分）の上限を $18.3 \%$ にすることが 2004 年度の公的 年金制度で定められていることから，その上限に合うよ う国庫分も合わせた保険料率（個人分十企業分十国庫分） の上限を $19.825 \%$ に設定する. 給付水準の下限は，2004 年度の公的年金制度改正で定められた值である。

Table 7 Policy variables for generation-based funding scheme 1

\begin{tabular}{ll}
\hline Policy variable & Set value \\
\hline $\begin{array}{l}\text { Age for the start of } \\
\text { contribution } \lambda_{G}\end{array}$ & 20 years old \\
Payment period $\mu_{G}$ & $\left(A_{\text {avg }}-20\right) \times 3 / 4$ \\
& years \\
Age for the start of & $\left(A_{\text {avg }}-20\right) \times 3 / 4+20$ \\
benefits $\nu_{G}$ & years old \\
\hline
\end{tabular}

Table 8 Policy variables for generation-based funding scheme 2

\begin{tabular}{ll}
\hline Policy variable & Set value \\
\hline Lower bound of insurance rate $\underline{\alpha}^{G}$ & $0 \%$ \\
Upper bound of insurance rate $\bar{\alpha}^{G}$ & $19.825 \%$ \\
Lower bound of benefit level $\underline{\beta}^{G}$ & $50 \%$ \\
Upper bound of benefit level $\bar{\beta}$ & $100 \%$ \\
Insured share of insurance & $6 / 13$ \\
Employee share of insurance & $6 / 13$ \\
Government share of insurance & $1 / 13$ \\
\hline
\end{tabular}

4.2.4 その他のデータ

その他のデー夕を Table 9 に示す.

Table 9 Simulation parameters

\begin{tabular}{ll}
\hline Parameter & Set value \\
\hline Starting year $T_{s}$ & 2005 \\
Ending year $T_{e}$ & 2100 \\
Longest lifetime $\xi$ & 119 years old \\
Oldest employment age $\chi$ & 99 years old \\
\hline
\end{tabular}

\section{3 シナリオ設定}

世代別積立方式への移行に関して 3 種類のシナリオを 設定し，それぞれシミュレーションを行う。

\section{Scenario 1}

世代別積立方式への移行を行わない.

\section{Scenario 2}

1989 年以前生まれ世代には現行方式を適用し，1990 年以降生まれ世代に順次世代別積立方式を適用する。 ただし，現行方式の政策変数の值にはすべて 2004 年度の公的年金制度改正で定められた值を用いる。

\section{Scenario 3}

1989 年以前生まれの世代には現行方式を適用し， 1990 年以降生まれの世代に順次世代別積立方式を適 用する。ただし，国庫負担率を 1.0 まで引き上げる．

\section{5. シミュレーション結果}

\section{1 積立金残高の推移}

Fig. 6 に現行方式下と世代別積立方式下の積立金残高 の合計を示す．ただし，2005 年を基準時点とし，賃金上 昇率で割り引いた值である。

シナリオ 1 では，保険料の上昇，年金額の下落，国庫 負担率の増加执よびマクロ経済スライドの適用により, 2040 年ころまでは積立金が増加するが，その後は保険料 納付者数拉よび年金受給者数の変化による財政収支の悪 化が顕著となり，2100 年ころにはゼロに近い值まで減少 している。

シナリオ 2 およびシナリオ 3 では，現行方式下の積立 金は減少するものの，世代別積立方式下にある世代別積 立金と変動準備金が急速に増加するため,すべての積立 金の合計は単調に増加している。

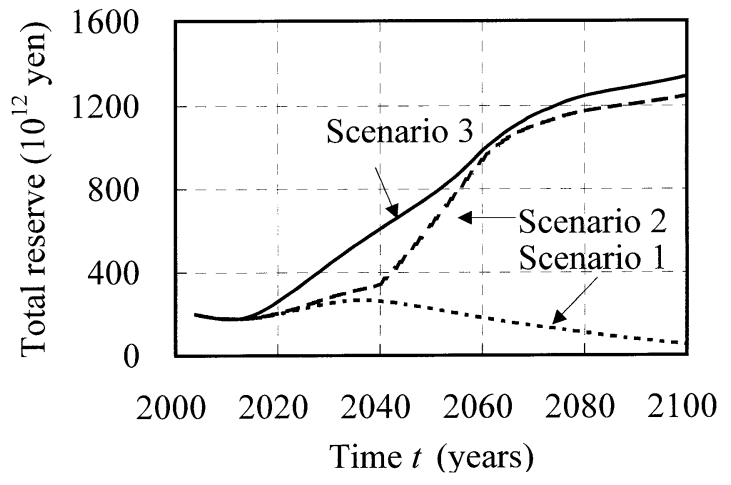

Fig. 6 Change in real value of year-end reserve

\section{2 国庫負担の推移}

Fig. 7 に国庫負担の推移を示す.ただし，積立金残高 と同様，2005 年を基準時点として賃金上昇率で割り引い た值である。

国庫負担率は 2009 年度までに $50 \%$ まで引き上げられ ることが 2004 年度の公的年金制度改正で定められてお り，シミュレーションでもそれを反映しているため，す ベてのシナリオで 2009 年に国庫負担が急増している. 
その後シナリオ 1 では，年金受給者のゆるやかな減少 によって国庫負担もゆるやかに減少している。

シナリオ 2 では，現行方式下の基礎年金支出に対する 国庫負担だけでなく，世代別積立方式下の保険料負担に 対する国庫負担が重なるため，2060年過ぎまではシナリ オ 1 よりも多い国庫負担が必要になる。また 2040 年頃 には，現行方式下で不足する年金原資を補うはずの変動 準備金が不足するため, 多額の国庫負担が必要になって いる．その金額は，2005 年価格で最大 40 兆円近くにも 上っており，事実上この移行方法は不可能といえる.

基礎年金の全額に国庫負担を充てるシナリオ 3 の場合, 当初シナリオ 2 に比べて国庫負担が増えるが，国庫負担 をあらかじめ多く投入することで積立金に余裕が生じ， シナリオ 2 のような突出した国庫負担が生じずに済んで いる.

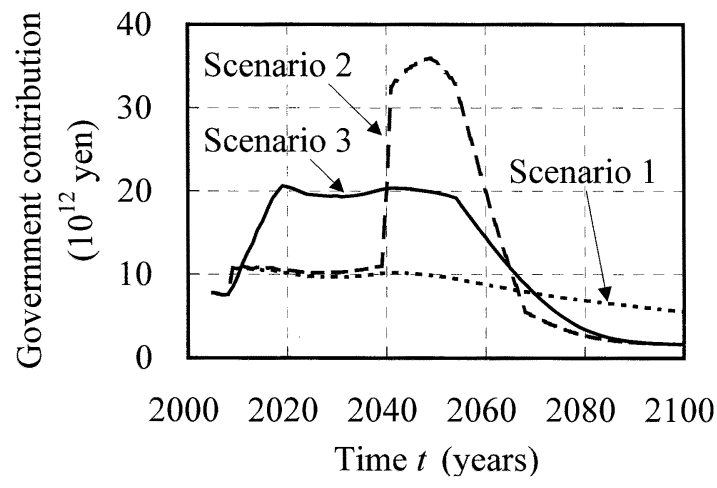

Fig. 7 Change in real value of government contribution

\section{6. おわりに}

本論文では，世代別積立方式に基づく公的年金制度へ の移行方法について提案を行った。これは，保険料負担 による公的扶助や家庭内での介護のような私的扶助をす でに行っている世代に対しては現行方式を適用し，そう でない世代には世代別積立方式を適用して負担給付比率 を一定に維持するという移行方法である。世代間公平性 の観点からいえば，すべての世代の負担給付比率を一定 にすることが良いと一見考えられる。しかしながら，す でに親の世代に対して私的扶助を行っている世代の負担 給付比率を推計することは容易でなく，また公的扶助に よる負担だけで負担給付比率を推計することは，世代間 公平性の観点から考えて問題があるといえる.

移行方法の提案に加え，移行が可能か否かを財政的な 観点から検討するため，現行方式の財政収支を定式化し， 2005 年から 2100 年までの財政の推移をシミュレートし た。年金の給付開始年齢や国庫負担率などの政策变数に 2004 年度の公的年金制度改正で定められた数值をその まま用いると 2005 年価格で最大 40 兆円近くもの国庫負 担が必要になるが，あらかじめ国庫負担率を 1.0 まで引 き上げることによって最大 20 兆円（2005 年価格）程度 まで国庫負担を抑制できる。
本論文では世代別積立方式への移行方法を検討したが， 今後は世代別積立方式の世代内公平性についても検討し， 世代内でどのように所得を再配分するか，被保険者個人 の年金額はいくらになるかなど，より詳細な財政方式の 設計・提案を行いたいと考えている.

\section{参考文献}

[1] 高山：厚生年金における世代間の再配分 ; 季刊現代経済, Vol. 43, No. 1, pp. 114-125 (1981)

[2] 野口：公的年金における受給・負担構造の世代間格差 一厚生省年金改革案に欠けている視点-；季刊現代経済， Vol. 57, No. 4, pp. 4-17 (1984)

[3] 濱本：公的年金の世代間格差に関する研究; 季刊社会保 障研究, Vol. 27, No. 4, pp. 431-441 (1992)

[4] 八田：厚生年金の積立方式への移行; シリーズ現代経 済研究 (八田, 八代編), 日本経済新聞社, Vol. 16, pp. 19-52 (1998)

[5] T. Hatta and N. Oguchi: Switching the Japanese social system from pay-as-you-go to actuarially fair; Routledge Contemporary Economics Policy Issues ( $\mathrm{T}$. Ihori and T. Tachibanaki, Eds.), Routledge, Vol. 4, pp. 113-131 (2002)

[6] D. Banjo, H. Tamura and T. Murata: On planning a public pension system under uncertainty: A generation-based operation model; CD-ROM Proc. of 2006 3rd International IEEE Conference "Intelligent Systems", pp. 150-155 (2006)

[7] D. Banjo, H. Tamura and T. Murata: Simulating a transition process to generation-based funding scheme in public pension planning; CD-ROM Proc. of 2007 IEEE International Conference on Systems, Man and Cybernetics, pp. 1993-1998 (2007)

[8] 番匠，田村，村田：世代間公平性と財政的持続可能性を 実現するための不確実性下における公的年金の最適計 画；システム制御情報学会論文誌, Vol. 51, No. 10, pp. 396-403 (2007)

[9] R. D. Lee and L. R. Carter: Modeling and forecasting U. S. mortality; Journal of the American Statistical Association, Vol. 87, pp. 77-104 (1992)

[10] 小松：リレーショナル・モデルによる日本の将来生命表 の試み; 人口問題研究, Vol. 58, No. 3, pp. 3-14 (2002)

\section{謝辞}

本研究の一部は, 文部科学省私立大学学術研究高度化 推進事業 社会連携研究推進事業 (平成 17 年度 平成 21 年度)による私学助成を得て行われた。 
